JIIP: Jurnal IImiah IImu Pemerintahan

Volume 6, Nomor 1, Tahun 2021

DOI: $10.14710 /$ jiip.v6i1.10083

\title{
Dampak Deforestasi Hutan Skala Besar terhadap Pemanasan Global di Indonesia
}

\author{
Herpita Wahyuni ${ }^{1}$ \& Suranto ${ }^{2}$ \\ 1,2 Departement of Government Affairs and Administration, Universitas \\ Muhammadiyah Yogyakarta
}

Dikirimkan: 9 Januari 2021

Direvisi: 1 Februari 2021

Diterbitkan: 25 Maret 2021

\begin{abstract}
INTISARI
Penelitian ini bertujuan untuk mengetahui perkembangan tingkat deforestasi di Indonesia dengan melihat implikasi dan upaya Indonesia dalam mengurangi deforestasi yang tentunya memberikan dampak baik terhadap pengurangan emisi atau pemanasan global. Penelitian ini menggunakan metode penelitian kualitatif yang bersumber dari berbagai literatur atau studi kepustakaan dalam menjawab hasil penelitian. Hasil temuan menemukan bahwa tingkat deforestasi di Indonesia masih tinggi. Deforestasi merupakan permasalahan yang memerlukan strategi dalam penguranganya, salah satunya dengan program REDD+ (Reducing Emissions from Deforestation and Forest Degradation). REDD+ berhasil menurunkan deforestasi setiap tahunnya karena adanya pendekatan dan kerjasama yang lebih dalam mengupayakan deforestasi serta pengurangan emisi atau pemanasan global. Dengan adanya REDD+ ini, beberapa daerah berusaha melakukan transformasi kebijakan untuk mendukung misi perbaikan ekologis dan deforestasi di kawasannya, sebagaimana terjadi di wilayah Pulau Kalimantan maupun di Nusa Tenggara Barat.
\end{abstract}

\section{KATA KUNCI}

deforetasi hutan; kerusakan lingkungan; pemanasan global

\section{Pendahuluan}

Hutan Indonesia adalah hutan yang sering disebut salah satu paru dunia yang menyumbangkan oksigen untuk keberlangsungan makhluk hidup yang dapat meyerap karbon dioksida yakni karbon yang berbahaya dan menghasilkan gas oksigen yang diperlukan oleh manusia (Shafitri, Prasetyo, \& Haniah, 2018). Hutan merupakan sumber daya alam yang berperan penting pada lini kehidupan, baik dari ekonomi, sosial, budaya, dan lingkungan (Widodo \& Sidik, 2020). Areal hutan yang semakin berkurang tentunya menyebabkan punahnya berbagai jenis spesies yang menyebabkan berbagai dampak termasuk menimbulkan efek gas rumah kaca (Novalia, 2017). Permasalahan lingkungan yang paling utama muncul teridentifikasi menjadi lima yang satu diantaranya yaitu

Korespodensi:

Departement of Government Affairs and Administration, Universitas Muhammadiyah Yogyakarta. Jl. Brawijaya, Geblagan, Tamantirto, Kec. Kasihan, Bantul, Daerah Istimewa Yogyakarta 55183.

Email: herpitawahyuni@yahoo.com 
kerusakan lahan yang disebabkan oleh penebangan hutan, dan alih fungi lahan untuk perkebunan (Akhmaddhian, 2016). Industri minyak sawit berperan dalam penghasil devisa terbesar di Indonesia yang dapat menyerap banyaknya tenaga kerja hingga luasnya lahan perkebunan kelapa sawit terus mengalami peningkatan secara signifikan (Purba \& Sipayung, 2017). Perkebunan kelapa sawit memiliki peran yang sangat strategis sebagai menunjang ekonomi secara nasional akan tetapi perkebunan kelapa sawit juga menimbulkan dampak negatif yakni dapat menimbulkan kerusakan lingkungan dan konflik sosial (Ngadi \& Noveria, 2018). Diperkirakan bahwa 57 \% deforestasi di negara Indonesia sebagian besar disebabkan oleh perubahan lahan menjadi yang menjadi lahan perkebunan kelapa sawit dan $20 \%$ lainnya bersumber dari pulp dan kertas (Ariana, 2017). Hampir disetiap tahunnya Indonesia dihadapkan dengan bencana kebakaran hutan, pada tahun 2015 tercatat 1,7 juta ha yang terbakar dan menyebabkan bencana asap yang menimbulkan dampak serius pada pendidikan, transportasi udara, kesehatan, ekonomi, dan tentunya kerusakan lingkungan (Adiputra \& Barus, 2018). Pembangunan dari sisi ekonomi diperlukanya perhatian terhadap pembangunan berkelanjutan yang tentunya memperhatikan berbagai aspek dari aspek sosial, ekonomi, dan lingkungan (Novalia, 2017).

Deforestasi adalah kondisi luas hutan yang mengalami penurunan yang disebabkan oleh konvensi lahan untuk infrastrukur, permukiman, pertanian, pertambangan, dan perkebunan (Addinul Yakin, 2017). Perubahan lahan hutan yang menjadi lahan non hutan menyebabkan pemanasan global karena akibat dari kebakaran hutan yang sering terjadi (Syah, 2017). Deforestasi berkaitan dengan penebangan atau pembalakan liar yang mengancam seluruh mahluk hidup yang pada umumnya diakibatkan oleh kebakaran hutan yang menyebabkan pemanasan global (Rimbakita, 2020). Pemanasan global adalah isu penting yang terjadi akibat aktivitas ekonomi yang dilakukan dengan tidak memperhatikan dampak lingkungan yang menyebabkan meningkatnya temperatur di bumi pada beberapa tahun terakhir (Prakoso, Ardita, \& Murtyantoro, 2019). Kerusakan hutan yang ada di Indonesia terus mengalami pentingkatan dan dapat diketahui bahwa hutan di Indonesia terus mengalami pengurangan disetiap tahunnya, hal tersebut memicu dampak buruk bagi Indonesia maupun dunia (Arif, 2016). Data dari Greenpeace, Indonesia adalah negara penyumbang emisi gas karbon ketiga setelah negara Amerika Serikat dan negara Tiongkok sekitar 80 $\%$ yang disebabkan oleh pembakaran hutan, pembakaran hutan juga menimbulkan dampak negatif terhadap kesehatan manusia seperti dapat menimbulkan sesak nafas berkepanjangan (Han, Goleman, Boyatzis, \& Mckee, 2019).

Pemanasan global adalah permasalahan yang kian dialami dan dirasakan oleh seluruh masyarkat di dunia dengan ditandai oleh kondisi peningkatan suhu yang semakin panas, kondisi cuaca yang tak menentu juga merupakan tanda-tanda terjadi 
pemanasan global. Pemanasan global ini bersumber dari berbagai aktivitas-aktivitas manusia dimulai dari kegiatan pembakaran bahan bakar fosil, industry, dan penggundulan hutan dengan besar-besaran yang tentunya menyebabkan timbulnya emisi karbon dengan dampak yang ditimbulkan yakni efek rumah kaca yang juga menimbulkan efek jangka yang panjang terhadap kehidupan, dan diharuskan dalam mengurangi aktivitas yang dapat merusak hutan atau kegiatan yang mampu menimbulkan emisi (Isti Prabandari, 2020). Fenomena meningkatnya suhu atau pemanasan global terjadi hampir diseluruh dunia sehingga memberikan dampak negatif terhadap indeks keberlanjutan lingkungan (Dewa \& Sejati, 2019). Sehingga dalam penelitian ini berfokus pada dampak yang ditimbulkan dari deforestasi atau penurunan luas hutan yang memicu terjadinya pemanasan global dan dapat diketahui upaya dalam mengurangi pemanasan global.

Penelitian ini mengunakan sumber-sumber dari berbagai studi terdahulu dengan bahan-bahan karya tulis atau studi kepustakaan (literature) yang dapat menjawab dari hasil penelitian tentang upaya pengurangan deforetasi hutan yang dianggap perlu untuk diteliti kerena banyaknya ketidakpahaman dari aktivitas-aktivitas masyarakat yang dapat menimbulkan dampak buruk terhadap kehidupan maupun lingkungan (Suliyanto, 2018). Fokus penelitian ini adalah melihat dampak yang ditimbulkan dari deforestasi atau penurunan luas lahan hutan yang merupakan permasalahan bangsa Indonesia yang setiap tahunnya kehilangan lahan hutan yang tidak sedikit dan dapat menimbulkan pemanasan global yang berdampak pada lingkungan, kehidupan sosial dan keberlanjutan hidup mahluk hidup lainnya.

\section{Deforestasi Hutan Indonesia}

Deforestasi merupakan kehilangan lahan hutan yang merupakan permasahan yang sulit untuk diatasi, sehingga diperlukan pengetahuan dan kerjasama yang baik antara berbagi elemen yang mampu menggerakkan masyarakat untuk dapat terlibat dalam pengurangan kegiatan atau mendukung progam-program yang dinilai mampu memecahkan permasalahan yang sedang dihadapi bersama (Forest Watch Indonesia, 2020). Tingkat deforestasi hutan di Indonesia di Tahun 1985 sampai 1998 melampaui 1, 6 sampai 1,8 hektar di setiap tahunnya (Education, 2017). Angka deforastai yang tinggi setiap tahunya akan menyebabkan hilangnya lahan hutan secara besar-besaran yang berdampak negatif pada keberlanjutan lingkungan maupun kehidupan sosial yang mampu menimbulkan efek buruk secara langsung maupun berdampak pada masa yang akan datang. Kemudian pada tahun 2000, deforetasi meningkat sekitar 2 juta hektar (Education, 2017). Data berdasarkan dari Kementerian Lingkungan Hidup dan Kehutanan (KLHK) bahwa pada masa Orde Reformasi hingga saat ini mengalami penurunan, dapat dilihat pada Tahun 2016 dan 2017 yang berada pada anggka 0,48 juta 
hektar. Pembaruan data pada beberapa Tahun terakhir yang bersumber dari KLHK bahwa dari data resmi menujukan pada tahun 2013 sampai 2014 bahwa deforestasi menurun di angka 0,4 juta hektar yan mana tahun sebelumnya pada angka 0, 73 juta hektar per tahunnya. Selanjutnya di tahun 2014-2015 tingkat deforestasi kembali naik menjadi 1,09 juta hektar, lalu tahun 2015-2016 kembali turun yang berada pada angka 0,63 juta hektar setiap tahunnya, dan kembali turun pada tahun 2016-2017 dengan angka 0,48 hektar pertahun. Laju deforestasi hutan dapat berkurang maupun meningkat setiap tahunnya yang diakibatkan oleh berbagai aktivitas manusia atau masyarakat, sehinga diperlukan kerjasama dan kesadaran bersama terhadap upaya yang dapat mengurangi deforestasi hutan yang akan berdampak positif terhadap lingkungan dan kesehatan masyarkat itu sendiri. Tingkat deforetasi di Negara Indoneisa dapat dilihat pada Gambar 1 di bawah ini.

\section{Gambar 1. Angka Deforestasi}

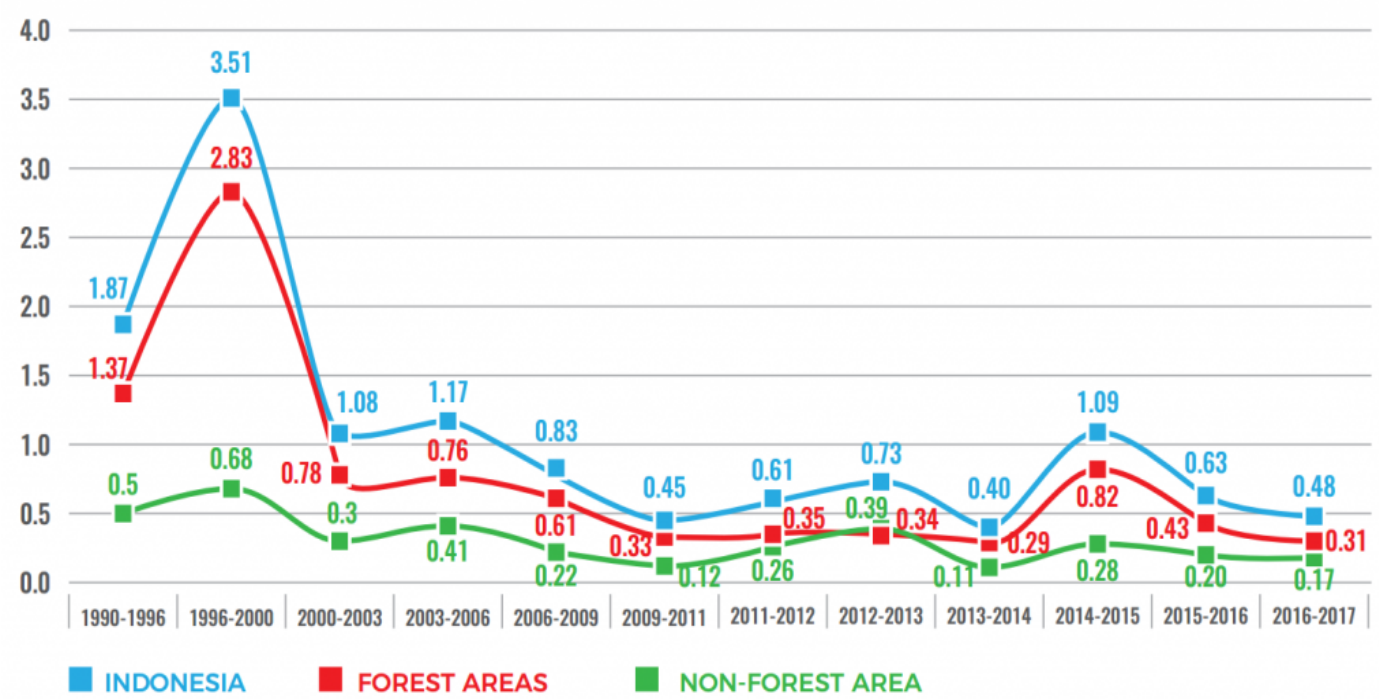

Sumber: Kementerian Lingkungan Hidup dan Kehutanan (KLHK, 2020)

Gambar di atas menyajikan angka deforestasi di Indonesia yang dapat diketahui bahwa tingkat deforestasi atau hilangnya lahan hutan terjadi pada Tahun 1985 hingga Tahun 1998 dengan angka sekitar 1,6 hingga 1,8 juta hektar setiap tahunnya, tingginya deforestasi hutan tentunya disebabkan oleh manusia itu sendiri. Selanjutnya Tahun 2000 tingkat deforestasi kian meningkat menjadi 2 juta hektar, Tahun 2013-2014 mengalami penurunan deforestasi pada 0,4 juta hektar per Tahunnya, selanjutnya pada di Tahun 2014-2015 kembali mengalami peningkatakan yakni pada angka 1,09 juta hektar disetiap tahunya, dan pada tahun 2016 sampai 2017 kembali mengalami penurunan yaitu pada 0,48 juta hektar. Permasalahan hutan yang terjadi di Indonesia 
sangat mengkhawatirkan pada tahun 1990 hingga 2017 diperkirakan sekitar rata-rata 0,5 juta hektar yang hilang setiap tahunnya (Publish What You Pay, 2020). Pengurangan jumlah deforestasi tentunya akan berdampak baik terhadap lingkungan, sehingga akan memberikan keasrian terhadap kehidupan maupun lingkungan. Memperjelas laju angka deforestasi dapat dilihat pada Tabel 1 di berikut ini.

Tabel 1. Deforestasi Menurut KLHK

\begin{tabular}{|c|c|c|}
\hline No & Tahun & Jumlah Deforestasi Hutan Per Tahun \\
\hline 1 & $1985-1998$ & 1,6 hingga 1,8 juta hektar \\
\hline 2 & 2000 & 2 juta hektar \\
\hline 3 & $2013-2014$ & 0,4 juta hektar \\
\hline 4 & $2014-2015$ & 1,09 juta hektar \\
\hline 5 & $2016-2017$ & 0,48 juta hektar \\
\hline
\end{tabular}

Sumber: KLHK https://fwi.or.id/menelisik-angka-deforestasi-pemerintah/

Data di atas menujukan bahwa setiap tahunnya lahan hutan di Indoensia terus mengalami deforestasi, dampak yang ditumbulkan dapat menyebabkan suhu yang semakin panas atau meningkat, sehingga dapat memicu dampak buruk terhadap makhluk hidup. Deforestasi adalah kondisi luas hutan yang mengalami penurunan yang disebabkan oleh konvensi lahan untuk infrastruktur, permukiman, pertanian, pertambangan, dan perkebunan (Addinul Yakin, 2017). Berbagai faktor penyebab terjadinya deforestasi yaitu: Konversi pertanian, kebakaran hutan, pemanenan kayu, dan penggunaan kayu bakar (Fund, 2020). Berbagai kegiatan yang dapat menyebabkan deforestasi akan berdampak yang serius terhadap kehidupan baik yang dapat dirasakan langsung oleh manusia, tumbuhan maupun hewan. Sehingga dapat diupayakan pengurangan yang mampu menjaga kelestarian alam Indonesia dengan upaya-upaya yang dioptimalkan dan kesadaran yang lebih antar sesama.

\section{Dampak Deforestasi Hutan Terhadap Pemanasan Global}

Deforestasi hutan merupakan ancaman bagi mahluk hidup, luas hutan yang mengalami penurunan yang disebabkan oleh konvensi lahan untuk infrastrukur, permukiman, pertanian, pertambangan, dan perkebunan (Yakin, 2015). Deforestasi di Indonesia menimbulkan dampak yang sangat serius baik pada tingkat nasional maupun tingkat internasional, adanya kebakaran hutan yang tidak terkendali, penebangan yang merusak, membuka lahan yang dijadikan perkebunan, pengerukan bahan bakar, dan pembangunan wilayah transmigrasi yang berdampak pada sosial ekonomi bagi masyarakat dengan kehidupannya yang sangat bergantung dengan hasil alam atau hutan, dan dapat menyebabkan timbulnya kerugian yang besar yakni bagi seluruh masyarakat maupun negara (Directorate of Technical Education, 2017). Studi baru kini kian mulai menyoroti tentang permasalahan pemanasan global yang menujukan bahwa 
negara Indonesia merupakan negara dengan penyumbang utama terhadap perubahan iklim dan kian rentan terhadap dampak-dampak yang ditimbulkan. Emisi Tahun 2000 di Indonesia dari sektor hutan dan perubahan terhadap peruntukan tanah diperkirakan mencapai 2.563 yang setara dengan megaton karbon dioksida $\left(\mathrm{MtCO}_{2} \mathrm{e}\right)$, Selanjutnya adanya emisi tahunan dari sektor energi, pertanian dan limbah yang besarnya mencapai $451 \mathrm{MtCO}_{2}$ e. Jika dibandingkan total emisi yang ada di negara Indonesia ialah mencapai 3.014 $\mathrm{MtCO}_{2} \mathrm{e}$, sedangkan emisi negara Cina mencapai 5.017 dan emisi Amerika Serikat mencapai hingga $6.005 \mathrm{MtCO}_{2} \mathrm{e}$. Tingkat deforestasi yang tinggi tidak hanya menyebabkan kerusakan pada alam namun dampak yang ditimbulkan akan berdampak pada kehidupan sosial masyarakat. Memperjelas data emisi dapat dilihat pada Tabel 2 berikut ini.

Tabel 2. Data Negara Penyumbang Emisi Tertinggi Tahun 2000

\begin{tabular}{|c|c|c|}
\hline No & Negara & Besaran $\mathrm{MtCO}_{2} \mathrm{e}$ \\
\hline 1 & Amerika Serikat & $6.005 \mathrm{MtCO}_{2} \mathrm{e}$. \\
\hline 2 & Cina & $5.017 \mathrm{MtCO}_{2} \mathrm{e}$. \\
\hline 3 & Indonesia & $2.563 \mathrm{MtCO}_{2} \mathrm{e}$. \\
\hline
\end{tabular}

Sumber: (Directorate of Technical Education, 2017), data diolah penulis

Data di atas menunjukan bahwa negara Indonesia adalah negara penyumbang emisi ketiga terbesar di dunia dengan besaran $2.563 \mathrm{MtCO}_{2} \mathrm{e}$ setelah negara Amerika dan Cina. Emisi yang tinggi dapat menyebabkan berbagai dampak serius diantaranya yaitu: Pertama, suhu mengalami peningkatan sejak 1990 sekitar 0,3 Derajat Celcius pada keseluruhan muslim. Kedua, meningkatnya 2 sampai $3 \%$ intensitas curah hujan setiap tahunnya dan menikatnya resiko bancana banjir secara signifikan. Ketiga, menimbulkan ancaman pangan dari akibat yang ditimbulkan dari perubahan iklim yang ekstrem, Keempat, permukaan air laut yang naik tentunya dapat menyebabkan tergenangnya daerah-daerah produktif pantai dan memberikan pengaruh terhadap penghidupan di daerah pantai. Kelima, bertambah hangatnya air laut memberi pengaruh terhadap kehidupan hayati laut dan menimbulkan ancaman pada terumbu karang. Keenam, menimbulkan berbagai penyakit yang dapat berkembang biak melalui media air dan vector yaitu penyakit malaria dan demam berdarah (Directorate of Technical Education, 2017). Isu lingkungan muncul sebagai pembicaraan politik sejak terdeteksinya berbagi ancaman terhadap penurunan kualitas lingkungan dengan menimbulkan ancaman terhadap keberlanjutan kehidupan manusia seperti menimbulkan rusaknya hutan, menghilangkan kesuburan tanah, langkahnya sumber daya air, tercemarnya udara dan berbagai permasalan lingkungan lainnya (Siswoko, 2008). Kerusakan-kerusakan yang ditimbulkan akan memberikan dampak lingkungan maupun sosial yang dapat dirasakan 
oleh masyarakat. Perubahan bentuk sebaran hutan akibat deforetasi dapat diamati pada Gambar 2 di bawah ini.

\section{Gambar 2: Perubahan Bentuk Sebaran Hutan Akibat Deforestasi}
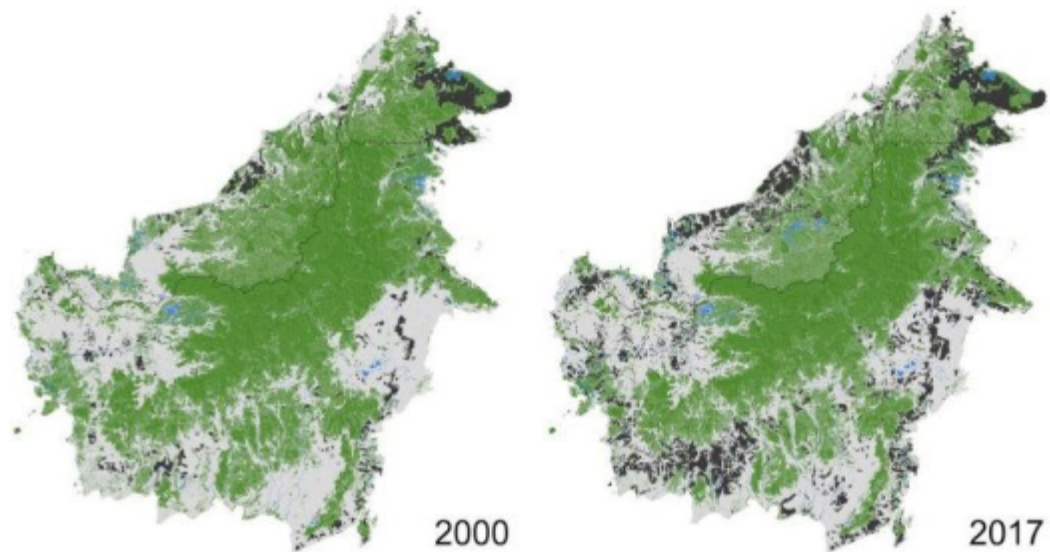

Sumber: (Allcott, 2020) https://www.cifor.org/

Berdasarkan peta lahan di atas yakni pulau Kalimantan memberikan informasi kehilangan lahan hutan di setiap tahun dari tahun 2020 sampai tahun 2017 yang diakibatkan oleh lahan yang digunkan untuk perkebunan kelapa sawit dan perkebunan kayu plup yang pada peta di atas ditandai dengan warna hitam, untuk hilangnya lahan hutan tersebut ditandai dengan warna hijau menjadi warna lain pada gambar tersebut. Pada warna hijau ke warna putih menandakan kehilangan lahan hutan, untuk penebangan hutan dan dikonversi menjadi pada tahun-tahun yang sama, ditandai dengan warna hijau menjadi hitam. Sedangkan pada warna hijau yang berati hutan dibuat bendungan secara permenen (Allcott, 2020). Indonesia memiliki luas wilayah di Kalimantan yaitu $73 \%$ dan 3, 74 juta hektar lahan tersebut hilang. Serta di pulau Kalimantan dengan pemilik Malaysia juga kehilangan lahan hutan dengan porsi lebih kecil yaitu 2,29 juta hektar hutan dan 1,85 juta hektar dipergunakan untuk lahan perkebunan. Gambar di atas memperjelas bahwa hutan di Indonesia terus mengalami pengurangan lahan yang disebebakan oleh konversi pertanian, kebakaran hutan, pemanenan kayu, dan penggunaan kayu bakar(Fund, 2020). Peran hutan yakni berperan untuk penyimpan cadangan-cadangan karbon secara besar dan mampu meyerap karbon dioksida berlebih yang ada di udara dan mengonversinya menjadi oksigen melalui proses fotosintesis yang dapat menyimpan karbon lebih dari dua ratus milyar ton. Sehingga deforestasi berpengaruh sangat besar terhadap perubahan iklim yang berkaitan dengan karbon-karbon yang ada di udara dan pada tanah gambut jika kehilangan pohon di atasnya maka akan melepaskan karbon yang tersimpan ke udara 
(Septiyan, 2019). Diperkirakan bahwa 57 \% deforestasi di Indonesia secara umum disebabkan oleh perkebunan kelapa sawit dan 20 \% lainnya bersumber dari pulp dan kertas (Ariana, 2017). Pentingnya peran hutan dalam mengurangi deforestasi dengan kemampuan hutan yang mampu menyimpan karbon dioksida dan diubah menjadi oksigen yang dibutuhkan oleh mahluk hidup, sehingga kelestarian hutan merupakan tanggung jawab bersama yang akan memberikan dampak baik untuk keberlanjutan mahluk hidup.

\section{Upaya Pengurangan Deforestasi}

Deforestasi yang makin meningkat dapat dilakukan upaya pengurangan agar laju tingkat deforestasi tidak mengalami peningkatan, berbagai upaya dapat dilakukan yaitu dengan melakukan penebangan dengan sistem tebang pilih yang mana sistem tebang pilih ini akan mampu menjaga dalam keberlangsungan ekosistem hutan dan berfungsi dalam penyangga kehidupan, pada sistem tebang pilih juga melakukan penanaman kembali agar kegiatan-kegiatan tersebut tidak menyebabkan kerugian. Kemudian dapat dilakukan dengan upaya reboisasi atau penghijauan yaitu melakukan penanaman kembali pada kawasan hutan, sedangkan melakukan penghijauan pada kawasan non hutan, karena hutan yang mengalamai gundul tak mampu menjalankan fungsinya dengan baik (Septiyan, 2019). Pengurangan deforestasi di Indonesia diselengarakan focus grup discussion (FDG) dengan merujuk pada upaya mengurangi deforestasi dan mengurangi degradasi hutan dengan berbagai kebijakan rencana pembangunan jangka menengah (RPJMN) 2020-2024. Berbagai strategi dalam upaya mengurangi deforestasi hutan yang tertuang di dalam (RPJMN) 2020-2024 yaitu mengurangi tingkat deforestasi menjadi 310 hektar/pertahun dengan melakukan penanaman kembali dan pengkayaan di hutan-hutan produksi dengan 1,97 juta hektar yang mana di dalamnya termasuk luas ekosistem gambut yang telah terkoordinasi dan difasilitasi restorasi pada 7 provinsi di Indonesia yang rentan terhadap bencana kebakaran dengan mencapai target 300.000 hektarnya pertahun. Selanjutnya untuk target dan strategi dalam pembangunan rendah karbon dengan melakukan pembangunan energi dengan sistem berkelanjutan, yakni melakukan pemulihan terhadap lahan yang keberlanjutan, adanya proses penanganan limbah, melakukan pengembangan industry hijau dan inventarisasi serta melakukan rehabilitas pada ekosistem pesisir dan area kelautan (Publish What You Pay, 2020). Berbagai kegiatan sederhana jika dilakukan dengan baik dan kerjasama atau kekompakan akan memberikan efek yang baik terhadap alam terutama dalam pengurangan emisi.

Bentuk keprihatinan terhadap deforestasi yang ditimbulkan adalah melahirkan REDD+ (Reducing Emissions from Deforestation and Forest Degradation) merupakan sebuah pendekatan konservasi lahan hutan dengan menggunakan skema keuangan 
dalam melakukan konservasi hutan yang menjadi usaha yang dapat memberikan keuntungan atau penghasilan dibandingkan melakukan penebangan hutan melalui pembayaran (Arild Angelsen, 2016). Pelaksanaan REDD+ dinilai perlu menjadi elemenelemen dalam proses mitigasi terhadap perubahan-perubahan iklim yang ada di negara Indonesia, mengingat pada COP 21 di Paris (Paris Agreement), bahwa negara Indonesia telah melakukan perjanjian bersama nationally determined contribution akan menurunkan emisi terhadap efek gas rumah kaca dengan melakukan upaya sendiri sekitar 29 \% dan menurunkan $41 \%$ emisi rumah kaca dengan bantuan internasional pada tahun 2030 mendatang (Nurbaya, 2018). Membentuk mekanisme penyelesaian kompleks dan mempercepat penyelesaian konflik yang dapat menciptakan kepastian tenuarial, meningkatakan transparasi dan partisipasi antar lembaga pemerintah di tingkat kabupaten maupun Provinsi dalam pelaksanaan REED+ (Angkawidjaja, 2020).

$R E D D+$ ini muncul dalam dua dimensi penting yaitu pertama, sebagai dimensi vertical dengan merujuk kepada seluruh gagasan dengan tujuan penurunan emisi dan meningkatkan proses penyerapan karbon dengan melibatkan semua elemen, kedua REDD+ sebagai dimensi horizontal dengan cangkupan sebagai tindakan lokal, subnasional, nasional, maupun global dengan bertujuan untuk pengurangan emisi akbiat deforetasi hutan (Septiyan, 2019). Tujuan dari REDD+ adalah melakukan penghitungan terhadap nilai karbon yang tersimpan di hutan, dengan upaya melakukan penawaran kepada negara berkembang dalam upaya mengurangi emisi dalam rangka investasi di jalur rendah karbon, sehingga dengan negara-negara maju dapat bekerjasama dengan membayar negara berkembang untuk pengurangan deforestasi di Indonesia, pembakaran lahan gambut, dan degradasi hutan (Shibao, 2015). Pelaksanaan $R E D D+$ di Indonesia dalam pelaksanaannya terbagi ke dalam tiga fase yakni: Pertama, fase persiapan yaitu tahun 2007-2008 dengan fokus pada identifikasi ilmu-ilmu pengetahuan dan berbagai kebijakan yang dapat mendukung. Kedua, fase kesiapan tahun 2008-2012 yang fokus pada metodelogi, dan kebijakan. Ketiga, fase implemntasi pasca tahun 2012 dengan harapan memperoleh keuntungan dari mekanisme REDD+ (Wahyuni, 2015). Berbagai strategi atau upaya yang dipersiapkan dan diimplementasikan yang memberikan hasil yang maksmal jika upaya dan kerjasama dilakukan dengan tepat dan juga maksimal.

Negara Indonesia telah menadatangani perjanjian bilateral tahun 2010 bersama dengan Negara Norwegia perihal REDD+ dengan isi perjanjian untuk pengurangan emisi dengan upaya menciptakan lembaga pemantauan dan pembatasan penggunaan lahan baru, serta menegakkan undang-undang tentang kehutanan yang ketat. Pemerintah Norwegia membayar Pemerintah Indonesia dapat mencapai hingga USD 1 miliar. Implementasi tersebut jika dilihat dari data satelit deforestasi di Indonesia masih terus mengalami peningkatan setelah perjanjian tersebut yakni tahun 2011-2012 
(Angkawidjaja, 2020). Kerjasama dalam pengurangan deforestasi kian membuahkan hasil di tahun 2019, yakni dimana bangsa Indonesia memperoleh bayaran pertama dengan proses waktu yang panjang yaitu dalam kurung waktu hingga sepuluh tahun. Lamanya waktu kerena sering terjadinya penundaan terkait pelaksanaan yang disebabkan oleh peleburan badan pengelolaan REDD+ dan peleburan kementerian kehutanan dengan kementrian lingkungan hidup pada masa pemerintah Joko Widodo (Angkawidjaja, 2020). Data dari BPS menujukan bahwa tingat deforestasi pada kawasan hutan di Indonesia tahun 2017-2018 mencapai 223.323,9 hektar per tahun, menurun mengalami dibandingkan pada tahun 2016-2017 yaitu 297.183,2 hektar per tahunnya, juga lebih kecil dibandingkan tahun pada 2015-2016 dengan 431.266,3 hektar per tahun. Data tersebut meunujukan adanya penurunan deforestasi, namun deforestasi ini masih tergolong tinggi dan tak menutup kemungkinan akan mengalami pemeningkatan pada tahun-tahun mendatang. Target dari NDC sektor kehutan dengan besaran (17,2\%) harus dapat mencapai target pada sepuluh tahun mendatang, sehingga penurunan emisi dari sektor hutan harus bisa melampaui $1,5 \%$ setiap tahunnya dan tentunya diperlukan kerjasama yang serius dari berbagai sektor (BPS, 2018).

Penandatangan kerjasama antara Pemerintah Indonesia dengan Pemerintah Norwegia dalam pengurangan emisi terkit pelaksanaan REED+ pada tahun 2010 telah membuka babak baru dalam upaya pengurangan emisi karbon dan tata Kelola hutan di Indonesia. Isi dari Kerjasama tersebut bahwa Indonesia akan berupaya mengurangangi dampak yang ditimbulkan dari kerusakan hutan. Namun terbentuknya REED+ sampai saat ini masih mengalami ketidakpastian. Penilaian REED+ di Indonesia Forest Watch Indonesia telah melakukan monitoring REED+ di daerah dan REED+ telah menandatangani MoU dengan beberapa pemerintah Daerah maupun di tingkat Provinsi serta Kabupaten. Tujuh Provinsi sudah menandatangai MoU dalam pelaksanaan REED+ dan penataan perizinan salah satunya di Kabupaten Barito Selatan di Kalimatan Tengah, di Kabupaten ini pelaksanaan REED+ difokuskan pada program pengurangan emisi deforestasi, degradasi hutan dan lahan gambut. Meskipun sudah ada MoU pelaksanaan REED+ ini masih sangat jauh dari harapan masyarakat kerena banyak masyarakat yang belum mengenal program REED+ ini dengan cukup jelas (Shibao, 2015).

Pelaksanaan REED+ di Indonesia memerlukan komitmen dalam mekanisme untuk mewujudkan pelaksanaan REDD+ yang efektif memerlukan komitmen dan inisiatif REED dan diperlukan keterlibatan para aktor (Salminah \& Wibowo, 2017). Pengurangan atau penurunan emisi dengan upaya membentuk REDD+ dengan daerah yang anggotanya dan melibatkan berbagai instansi (Syafri \& Endrizal, 2019). Keberhasilan REED+ dengan pelaksanaan pemerintah yang tegas dalam menghentikan perpanjangan izin, adanya upaya dalam penyelamatan hutan yang kian terancam, dan adanya upaya penyelesaian masalah masyarakat (Ekawati et al., 2019). 
Berbagai kegiatan sudah mulai dilakukan di Kalimatan Tengah seperti kegiatan yang sudah mengupayakan melibatkan masyarakat seperti pelaksanaan penyusunan RPJMD yang membahas tentang desa hijau, peningkatan ekonomi alternatif seperti: pengembangan kerambah ikan dan pengembangan petani karet, akan tetapi belum memperoleh hasil yang maksimal (Nurbaya, 2018). Lombok, West Nusa Tenggara dalam pelaksanaan REED+ dilaksanakan pada wilayah kerja hutan kemasyarakatan, lokasi area pelaksanaan REED+ di kabupaten Lombok Tengah yang tidak memerlukan penataan batas ulang terhadap Kawasan hutan tersebut. Pelaksanaan penataan batas sudah berjalan dengan baik, akan tetapi dalam pelaksanaan REED+ di Kabupaten Lombok Tengah belum berjalan dengan sesuai ketentuan yang ada. Pelaksaan REED+ di Lombok Tengah terdapat berberapa kegiatan yang tidak transparan dari perencanaan hingga anggaran pelaksanaan REED+. Prinsip-prinsip partisipasi, koordinsi dan transparansi di Lombok Tengah dalam program REED+ belum terlihat secara nyata. (Syah, 2017). Temuan Forest Watch Indonesia di lapangan bahwa diperlukanya pemahaman tentang pemanfaatan hutan dan lahan dalam rangkat pemanfaatan REED+ di daerah dalam konteks pemenuhan hak masyarakat baik infromasi, partisipasi, dan akuntablitas melalui pengelolaan peningkatan teknis yang mendorong terlaksananya aspek transparansi dan partisipasi dalam pengambilan kebijakan. Pergeseran pardigma pembangunan hijau dengan penurunan emisi dan pembangunanan efisien yang mempertahankan sumber daya alam adalah jalan paling terang menuju pertumbuhan ekonomi yang mensejaterakan masyarakat Indonesia dan ikut serta dalam penyelesaian masalah perubahan iklim

\section{Penutup}

Deforestasi adalah bentuk kehilangan lahan hutan yang merupakan ancaman bagi mahluk hidup, luas hutan yang mengalami penurunan yang disebabkan oleh konvensi lahan untuk infrastrukur, permukiman, pertanian, pertambangan, dan perkebunan yang menimbulkan dampak serius yaitu menimbulkan pemanasan global. Emisi yang tinggi dapat menyebabkan berbagai dampak serius diantaranya yaitu: suhu mengalami peningkatan, meningkatnya intensitas curah hujan per tahun yang mengakibatkan bencana, menimbulkan ancaman pangan dari perubahan iklim yang ditimbulkan, permukaan air laut yang naik tentunya dapat menyebabkan tergenangnya daerah produktif pantai dan memberikan pengaruh terhadap penghidupan masyarakat pantai, bertambah hangat air laut akan mempengaruhi kehidupan hayati laut dan menimbulkan ancaman pada terumbu karang, menimbulkan berbagai penyakit yang dapat berkembang biak melalui media air dan vector seperti penyakit malaria dan demam berdarah. 
Keprihatinan terhadap deforestasi dari dampak yang ditimbulkan telah melahirkan $R E D D+$ dengan upaya menghitung nilai karbon yang tersimpan dalam lahan hutan dan memberikan penawaran kepada negara berkembang untuk dapat terlibat dalam pengurangan emisi dalam rangka investasi di jalur rendah karbon, sehingga dengan kata lain negara maju membayar negara berkembang untuk mengurangi tingkat deforestasi, pembakaran lahan gambut, dan degradasi hutan. Pelaksanaan REED+ adalah upaya dalam mengurangi emisi dengan upaya yang dilakukan seperti kegiatan yang mengupayakan melibatkan masyarakat seperti pelaksanaan penyusunan RPJMD di Kalimatan yang membahas tentang desa hijau, peningkatan ekonomi alternatif seperti: pengembangan kerambah ikan dan pengembangan petani karet dan di wilayah Lombok, West Nusa Tenggara dalam pelaksanaan REED+ dilaksanakan pada wilayah kerja hutan kemasyarakatan, lokasi area pelaksanaan REED+ di kabupaten Lombok Tengah yang tidak memerlukan penataan batas ulang terhadap Kawasan hutan tersebut. Pelaksanaan penataan batas sudah berjalan dengan baik, akan tetapi dalam pelaksanaan REED+ di Kabupaten Lombok Tengah belum berjalan dengan sesuai ketentuan yang ada. Pelaksannan REED+ yang diharapakan dapat mempercepat penyelesaian konflik yang dapat menciptakan kepastian tenuarial, meningkatakan transparasi dan partisipasi antar lembaga pemerintah di tingkat kabupaten maupun Provinsi.

\section{Ucapan Terima Kasih}

Terima kasih kepada para dosen di Universitas Muhammadiyah Yogyakarta yang telah mendukung untuk menyelesaikan karya ini.

\section{Pendanaan}

Penulis tidak menerima bantuan pembiayaan untuk penelitian, kepenulisan (authorship), dan publikasi dari pihak manapun.

\section{Daftar Pustaka}

Addinul Yakin. (2017). Prospek Dan Tantangan Implementasi Pasar Karbon Bagi, (September).

Adiputra, A., \& Barus, B. (2018). Analisis Risiko Bencana Kebakaran Hutan Dan Lahan Di Pulau Bengkalis. Jurnal Geografi Edukasi Dan Lingkungan (JGEL), 1(2), 55-62.

Akhmaddhian, S. (2016). Penegakan Hukum Lingkungan dan Pengaruhnya Terhadap Pertumbuhan Ekonomi di Indonesia (Studi Kebakaran Hutan Tahun 2015). UNIFIKASI: Jurnal IImu Hukum, 3(1).

Allcott, H. (2020). Polarization and Public Health: Partisan Differences in Social Distancing during the Coronavirus Pandemic. Retrieved from 
http://web.stanford.edu/ gentzkow/research/social_distancing.pdf

Angkawidjaja, M. (2020). Lika-Liku Pelaksanaan REDD+ Di Indonesia: Efektifkah Atasi

Deforestasi? Retrieved from https://fh.unpad.ac.id/lika-liku-pelaksanaan-redd-diindonesia-efektifkah-atasi-deforestasi/

Ariana. (2017). 3 Cara untuk Mengatasi Deforestasi Hutan Tropis Hingga 2020.

Arif, A. (2016). Analisis Yuridis Pengerusakan Hutan (Deforestasi) Dan Degradasi Hutan Terhadap Lingkungan. Jurisprudentie, 3, 33-41.

Arild Angelsen. (2016). Menganalisis REDD+: Sejumlah Tantangan Dan Pilihan.

BPS. (2018). Badan Pusat Statistik, 'Angka Deforestasi Netto Indonesia Di Dalam Dan Di Luar Kawasan Hutan Tahun 2013-2018 (Ha/Th)', Bps.Go.Id, 2020.

Dewa, D. D., \& Sejati, A. W. (2019). Pengaruh Perubahan Tutupan Lahan Terhadap Emisi GRK pada Wilayah Cepat Tumbuh di Kota Semarang. Jurnal Penginderaan Jauh Indonesia, 1(1), 24-31.

Directorate of Technical Education. (2017). Perubahan Iklim, "Pencegahan Deforestasi" dan Indonesia.

Education, D. of T. (2017). Prubahan Iklim, "Pencegahan Deforestasi” dan Indonesia.

Ekawati, S., Dharmawan, I. W. S., Wardoyo, W., Rusolono, T., Anwar, S., \& Sabarudi. (2019). Membumikan Program REDD+ di Kalimantan Timur.

Forest Watch Indonesia. (2020). Menelisik Angka Deforestasi Pemerintah. https://fwi.or.id/menelisik-angka-deforestasi-pemerintah/.

Fund, W. W. (2020). 2020's Most Epic Conservation Wins. Retrieved from https://www.worldwildlife.org/

Han, E. S., Goleman, D., Boyatzis, R., \& Mckee, A. (2019). Lahan dan Hutan Dalam Skala Besar. Journal of Chemical Information and Modeling, 53(9), 1689-1699.

Isti Prabandari, A. (2020). Pengertian Pemanasan Global dan Dampaknya, Timbulkan Berbagai Gangguan Cuaca Ekstrem.

Ngadi, N., \& Noveria, M. (2018). Keberlanjutan Perkebunan Kelapa Sawit Di Indonesia Dan Prospek Pengembangan Di Kawasan Perbatasan. Masyarakat Indonesia, 43(1).

Novalia, T. (2017). Neraca Lahan Indonesia: Penyusunan Neraca Lahan Indonesia untuk Mendukung Implementasi Sustainable Development Goals, 245-254.

Nurbaya, S. (2018). Status Hutan \& Kehutanan Indonesia 2018. Retrieved from https://sitinurbaya.com/

Prakoso, S. G., Ardita, N. D., \& Murtyantoro, A. P. (2019). Analisis Diplomasi Soft Power Denmark Terhadap Indonesia (Studi Tentang Kerja Sama Pengelolaan Lingkungan di Indonesia)[An Analysis of Denmark's Soft Power Diplomacy in Indonesia (A Study nn Environmental Management Coorperation in Indonesia)]. Jurnal Politica Dinamika Masalah Politik Dalam Negeri Dan Hubungan Internasional, 10(1), 5776. 
Publish What You Pay. (2020). Pengurangan Deforestasi dan Degradasi Hutan dalam Kebijakan Rencana Pembangunan Jangka Menengah (RPJMN) 2020-2024.

Purba, J. H. V, \& Sipayung, T. (2017). Perkebunan Kelapa Sawit Indonesia dalam Perspektif Pembangunan Berkelanjutan. Jurnal IImu-IImu Sosial Indonesia, 43(1), 81-94.

Rimbakita. (2020). Deforestasi - Pengertian, Penyebab, Akibat \& Cara Mencegah Penebangan Hutan. Retrieved from https://rimbakita.com/deforestasi/

Salminah, M., \& Wibowo, A. (2017). Synchronization Of Redd+ National Policy With Stakeholders'interest In Subnational Level. Jurnal Analisis Kebijakan Kehutanan, 14(2), 105-120.

Septiyan, A. R. (2019). Deforestasi: Pengertian, Penyebab, Dampak, dan Pencegahan. Retrieved from https://foresteract.com/deforestasi/

Shafitri, L. D., Prasetyo, Y., \& Haniah, H. (2018). Analisis Deforestasi Hutan di Provinsi RIAU dengan Metode Polarimetrik dalam Pengindraan Jauh. Jurnal Geodesi Undip, 7(1), 212-222.

Shibao, P. (2015). Fighting Fire With Money: Can Finance Protect Indonesia's Forests? Retrieved from https://news.mongabay.com/2015/04/fighting-fire-with-moneycan-finance-protect-indonesias-forests/

Siswoko, B. D. (2008). Pembangunan, Deforestasi dan Perubahan Iklim (Development, Deforestation and Climate Change). Jurnal Manajemen Hutan Tropika, 14(2), 8996.

Suliyanto, P. (2018). Metode Penelitian Bisnis untuk Skripsi. Tesis \& Disertasi. Yogyakarta: Andi.

Syafri, E., \& Endrizal, N. (2019). Arti Penting Pelaksaan REDD + Bagi Indonesia: Tantangan dan Hambatan yang Akan Dihadapi. Journal of Chemical Information and Modeling, 53(9), 1689-1699.

Syah, R. F. (2017). Analisa Kebijakan Sektor Lingkungan: Permasalahan Implementasi Kebijakan Pengelolaan Kawasan Hutan di Indonesia. Journal of Governance, 2(1), 2-17.

Wahyuni, T. (2015). Pembelajaran dari Projek Percontohan REDD+ pada Fase Persiapan dan Kesiapan. Jurnal Sosioteknologi, 14(1), 37-48.

Widodo, P., \& Sidik, A. J. (2020). Perubahan Tutupan Lahan Hutan Lindung Gunung Guntur Tahun 2014 Sampai dengan Tahun 2017. Wanamukti: Jurnal Penelitian Kehutanan, 21(1), 30-48.

Yakin, A. (2015). Prospek dan Tantangan Implementasi Pasar Karbon bagi Pengurangan Emisi Deforestasi dan Degradasi Hutan di Kawasan ASEAN. In Paper disampaikan pada Seminar Nasional "Optimalisasi Integrasi Menuju Komunitas ASEAN. 
H. Wahyuni \& Suranto $\begin{aligned} & \text { Dampak Deforestasi Hutan Skala Besar terhadap Pemanasan Global } \\ & \text { di Indonesia }\end{aligned}$

\section{Tentang Penulis}

Herpita Wahyuni adalah Mahasiwi Master Departement of Government Affairs and Administration, Universitas Muhammadiyah Yogyakarta. Penulis memiliki riset seputar tema Mitigasi Bencana kajian Gunung Merapi Sleman Yogyakarta.

Suranto adalah Dosen Department of Government Affairs and Administration, Jusuf Kalla School of Government, Universitas Muhammadiyah Yogyakarta. Penulis ahli dan banyak memiliki riset kajian Policy Analysis dan Local Government. 